\title{
KEBIJAKAN PENINGKATAN KUALITAS PELAYANAN KESEHATAN MASYARAKAT MISKIN DI KABUPATEN PROBOLINGGO
}

\author{
Irtanto $^{1}$, Slamet Hari Sutanto ${ }^{2}$ \\ 1,2 Research and Development Board of East Java Province - Indonesia \\ Email: rtanto@rocketmail.com
}

\begin{abstract}
This research uses the concurrent embedded design approach. The objective of this research is to identify the regional regulation of Probolinggo Regency in the health sector in an effort to improve the quality of lower-class health services and the factors or obstacles in the implementation of health policies as well as to know the quality of the health services delivered to that poor community. The results show that the provision of lower-class health services is in the form of JKN membership (Jaminan Kesehatan Nasional or National Health Insurance) held by BPJS (Badan Penyelenggara Jaminan Sosial or Social Security Agency) in the health sector through PBI (Penerima Bantuan Iuranor Beneficiaries); Jamkesda (Jaminan Kesehatan Daerah or Regional Health Insurance) funds sharingparticipants; through a statement of incapacity (SKTM or Surat Keterangan Tidak Mampu). In this matter, the policy is in the form of Regent Decree number 12 of 2015 concerning the lower-class health services which are not included in JKN and Jamkesda at RSUD Waluyo Jati Kraksaan Probolinggo (Waluyo Jati Kraksaan Probolinggo Regional Public Hospital). The factor which becomes the obstacle in the policy implementation is the lack of specialist doctors such as a dermatologist and surgeon. The regional budget also becomes a barrier to meet various health facilities and infrastructure. Besides that, the problem from the lower class itself is the reluctance of the family to be referred to a government hospital (East Java Province) due to their incapability to meet the living and transportation expenses while they wait for the patient. Therefore, quantitatively, the policy implementation to improve the lowerclass health services is able to make a positive contribution to the quality of health services in a public hospital. It is also known that various variable indicators are in a good category. Nevertheless, certain indicators still not good and need deep improvements in the service.
\end{abstract}

Article Histori:

Submited: $23 / 08 / 2018$

Review: 25/09/2018

Editing: 25/04/2019

Publish: 29/04/2019

Keyword: Health Policy, Service Quality, Lower-Class Community.

\section{PENDAHULUAN}

Pemerintah Indonesia berkewajiban untuk memperhatikan kesehatan setiap warga negaranya, seperti diamanatkan dalam Pembukaan UUD 1945 antara lain menyebutkan melindungi segenap bangsa
Indonesia dan seluruh tumpah darah Indonesia dan untuk memajukan kesejahteraan umum, dan keadilan sosial. Negara Indonesia menganut doktrin kesejahteraan sosial (social welfare) yang secara jelas tercantum dalam pasal 27, 33 
dan 34 UUD 1945. Konstitusi negara Indonesia telah mengamanatkan kepada pengelola negara untuk membangun negara dan bangsa Indonesia berlandaskan paham kesejahteraan. Peran negara dalam doktrin negara kesejahteraan (welfare state) mutlak harus dilakukan. Dalam konteks ini negara mempunyai peran yang sangat penting untuk membangun sistem yang dapat mewujudkan kemakmuran dan kesejahteraan bagi masyarakat Indonesia. Oleh karena itu, kebijakan sosial harus memberikan prioritas yang memadai dalam meningkatkan belanja sosial, terutama untuk peningkatan pelayanan kesehatan.

Berbagai kebijakan bidang kesehatan di Indonesia dari kurun waktu ke waktu mengalami berbagai perubahan yang cukup mendasar. Perhatian pemerintah di bidang kesehatan akan nampak bila dilihat dari dukungan anggaran keuangan yang disediakan oleh pemerintah. Amandeman UU No 23/1999 tentang Kesehatan menyebutkan bahwa tiap daerah harus menganggarkan minimal 15\% dari APBD untuk kesehatan. Dalam UU RI No. 36 tahun 2009 tentang kesehatan, besaran anggaran untuk pemerintah pusat diatur dalam pasal 171 ayat 1 yaitu pemenuhan alokasi anggaran kesehatan untuk pusat (APBN) sebesar 5\%. Besaran anggaran untuk daerah (APBD Provinsi/Kabupaten/Kota) diatur dalam pasal 171 ayat 2 yaitu $10 \%$ dari total anggaran setiap tahunnya diluar gaji pegawai. Kemudian pasal 171 ayat 3 menyebutkan bahwa besaran anggaran kesehatan tersebut diprioritaskan untuk kepentingan pelayanan publik (terutama bagi penduduk miskin, kelompok lanjut usia, dan anak terlantar) yang besarannya sekurang-kurangnya 2/3 (dua pertiga) dari anggaran kesehatan dalam APBN dan APBD.

Namun realitasnya, sejak 2005 ratarata anggaran kesehatan hanya dialokasikan 2\% dari belanja APBN. Bahkan sejak diberlakukan UU No. 36/2009 tentang kesehatan yang mengamanatkan anggaran kesehatan 5\%, anggaran kesehatan secara nasional justeru terus menurun. Pada tahun 2009 dan tahun 2010 anggarandi bidang kesehatan hanya 3,0\% dari total APBN, belum lagi anggaran kesehatan khusus untuk masyarakat miskin tentunya lebih kecil lagi, masih jauh dari yang disarankan oleh WHO, sebesar 15\%. Anggaran sebesar 3,0\% dipakai untuk keperluan berbagai kebutuhan: fasilitas kesehatan, pelayanan kesehatan dan obatobatan, jaminan kesehatan masyarakat (Jamkesmas), alat kesehatan, ambulans dan lain sebagainya. Dari total anggaran APBN ini belum lagi dirinci secara pasti berapa untuk kesehatan masyarakat msikin, tentunya jumlahnya lebih kecil. Minimnya anggaran kesehatan secara nasional juga nampak pada tahun 2011 hanya sebesar 3,3\%, tahun 2012 sebesar 3,1\%, tahun 2013sebesar 3,3\% dan tahun 2014 sebesar 3,8\% dari total APBN.Sedangkan anggaran kesehatan untuk masyarakat miskin yang berada di bawah kementerian kesehatan dari tahun 2009 sampai 2014 secara kuantitas ada kecenderungan mengalami kenaikan. Namun mengalami penurunan di tahun 2016 dan 2017. 
Tabel 1. Anggaran Kementerian

\begin{tabular}{ccc}
\multicolumn{3}{c}{ Kesehatan RI untuk Masyarakat Miskin } \\
\hline No. & $\begin{array}{c}\text { Tahun } \\
\text { Anggaran }\end{array}$ & $\begin{array}{c}\text { Besaran Angggaran } \\
\text { (Triliun Rupiah) }\end{array}$ \\
\hline 1 & 2009 & 11,5 \\
2 & 2010 & 14,0 \\
3 & 2011 & 17,4 \\
4 & 2012 & 19,4 \\
5 & 2013 & 22,6 \\
6 & 2015 & 26,2 \\
7 & 2016 & 24,8 \\
8 & 2017 & 25,4 \\
\hline
\end{tabular}

Sumber: diakses dari

http://www.anggaran.depkeu.go.id dan www.depkes.go.id (7/6/2018).

Perubahan kebijakan nasional di bidang kesehatan secara radikal adalah program JKN (Jaminan Kesehatan Nasional) yang dibentuk berdasarkan UU No. 40 tahun 2004, tentang Sistem Jaminan Sosial Nasional (SJSN). UU tersebut memerintahkan dibentuknya BPJS, dengan tujuan supaya menjalankan JKN. Sebagai tindaklanjutnya kemudian dibentuklah UU No. 24 th 2011, tentang BPJS. BPJS Kesehatan merupakan transformasi dari PT Asuransi Kesehatan(Askes), untuk kepesertaannya merupakan mantan peserta Askes, seperti PNS, Pensiunan PNS, TNI, Polri, dan veteran. Selain itu kepesertaan BPJS kesehatan ditambah dengan TNI dan Polri yang masih aktif, yang dulunya dicover oleh Asabri. Tidak hanya itu, pekerja penerima upah dari perusahaan yang dulu di-cover Jaminan Sosial Ketenagakerjaan (Jamsostek) juga masuk ke dalam BPJS Kesehatan. Kemudian program pemerintah berupa Jaminan Kesehatan Masyarakat (Jamkesmas) kepesertaannya juga masuk ke dalam BPJS Kesehatan. Kemudian program pemerintah daerah mengenai Jaminan Kesehatan Daerah (Jamkesda), kepesertaannya dialihkan ke BPJS Kesehatan pada tahun 2015. Oleh karena itu peserta BPJS Kesehatan dapat dibedakan menjadi 2 (dua) golongan yaitu Penerima Bantuan Iuran (PBI) dan non BPI. Mereka masuk dalam BPI adalah yang tidak mampu dalam segi finansial, iurannya dibayarkan oleh pemerintah. Sedangkan yang non PBI iurannya dibayarkan oleh pemberi kerja atau pekerja itu sendiri yang membayar dari penghasilannya.

Namun dalam implementasinya BPJS kesehatan yang diperlakukan sejak Januari 2013 masih saja mengalami berbagai kendala seperti berbelit-belitnya pelayanan, pembatasan pelayanan, dan minimnya penyediaan obat dan sistem rujukan yang tidak bagus dan terbatas, pelayanan ruang inap.Selain itu hanya satu (1) tindakan rehabilitasi medik saja, tidak boleh lebih.Kondisi ini berarti pelayanan kesehatan yang tidak tercover dalam program pelayanan kesehatan seperti BPJS menjadi tanggung jawab masyarakat tanpa harus melihat latar belakang kemampuan mereka. Padahal menurut data BPS Provinsi Jawa Timur, bahwa angka kimiskinanKabupaten Probolinggoyang merupakan lokasi penelitian pada tahun 2013sampai 2017 merupakan daerah miskin. Kemiskinan tersebut dapat dilihat dalam tabel 2 berikut ini.

\section{Tabel 2. Jumlah Penduduk Miskin di Provinsi Jawa Timur dan Kabupaten Probolinggo (\%)}

\begin{tabular}{cccc}
\hline No & Tahun & $\begin{array}{c}\text { Provinsi } \\
\text { Jawa } \\
\text { Timur (\%) }\end{array}$ & $\begin{array}{c}\text { Kabupaten } \\
\text { Probolinggo } \\
\text { (\%) }\end{array}$ \\
\hline 1 & 2012 & 13,08 & 22,15 \\
2 & 2013 & 12,73 & 21,21 \\
3 & 2014 & 12,28 & 20,44 \\
4 & 2015 & 12,34 & 20,82 \\
5 & 2016 & 12,05 & 20,98 \\
6 & 2017 & 11,20 & 20,52 \\
\hline
\end{tabular}

Sumber: BPS Jawa Timur 2017. METODE

Penelitian ini menggunakan pendekatan concurrent embedded desigen 
yaitu merupakan metode penelitian kualitatif dan kuantitatif secara simultan atau bersama-sama, tetapi bobot metodenya berbeda. Metode tersebut digunakan secara bersama-sama, dalam waktu yang sama (Sugiyono, 2013: 537). Pada model ini ada metode yang primer dan metode yang sekunder. Metode primer digunakan untuk memperoleh data yang utama, dan metode sekunder digunakan untuk memperoleh data guna mendukung data yang diperoleh dari metode primer. Metode primernya dalam penelitian disini adalah kualitaif, sedangkan sekundernya adalah angka-angka dalam bentuk deskriptif kuantitatif digunakan hanya untuk memdukung kualitatif, terutama dampak kebijakan terhadap kualitas layanan. Adapun tujuan dari penelitian ini adalah mengidentifikasi kebijakan Pemerintah Daerah Kab. Probolinggo di bidang kesehatan dalam upaya meningkatkan kualitas pelayanan kesehatan masyarakat miskin, dan faktorfaktor yang menjadi hambatan dalam mengimplementasikan kebijakan kesehatan, serta mengetahui kualitas pelayanan kesehatan di RSUD Pemerintah Daerah Kab. Probolinggo terhadap masyarakat miskin.

Lokasi penelitian Kabupaten Probolinggo. Dalam penelitian ini obyek penelitiannya adalah Dinas Kesehatan Kab. Probolinggo dan RSUD Waluyo Jati Kraksaan Kabupaten Probolinggo. Informan penelitian ini adalah pejabat pengambil kebijakan di bidang kesehatan yaitu pejabat Dinas Kesehatan, Pejabat
Rumah Sakit, Dokter dan perawat yang berstatus PNS.

Teknik pengumpulan data dilakukan secara trianggulasi yaitu wawancara mendalam (indepth interview)/FGD, observasi partisipan, studi dokumentasi dan kuesioner.

Analisis data kualitatif mengikuti pendapat Miles dan Huberman (2014) bahwa pengumpulan data dan analisis data dilakukan bersamaan secara interaktif, yaitu data condensation, data display, dan conclusions: drawing/verification. Penelitian ini menggunakan metode analisis data situs tunggal (Miles \& Haberman;, Bogdan \& Biklen, 1998; Yin, 2004). Selanjutnya metode skunder deskriptif kuantitaif untuk melihat kualitas layanan rumah sakit terhadap masyaraat miskin. Metode skunder yang bersifat deskriptif kuantitatif menggunakan teknik pengambilan sampel dengan menggunakan teknik kuota sampling dengan ditentukan sampel sebanyak 150 orang pasien/keluarga, dengan komposisi 50 orang pasien rawat inap laki-laki, 50 orang pasien perempuan dan 50 orang pasien rawat jalan. Pengambilan sampel sebanyak ini menggunakan pedoman dari Roscoe (1975) yang mengusulkan ukuran sampel lebih dari 30 dan kurang dari 500 adalah tepat untuk kebanyakan penelitian (dalam Uma Sekaran (2006).

Penilaian pasien miskin terhadap kualitas pelayanan kesehatan dibagi kedalam aspek sarana dan prasarana, sistem dan prosedur, dan kualitas aparatur pelayanan kesehatan. Sedangkan penetapan skoringnya menggunakan skala 
likert dengan memberikan 4 (empat) alternatif jawaban, yaitu: a) nilai 1 terendah untuk jawaban tidak baik; b) nilai 2 untuk jawaban kurang baik; c) nilai 3 untuk jawaban baik; d) nilai 4 merupakan nilai sangat baik.Nilai kualifikasi ditentukan oleh jumlah dari frekuensi jawaban dikali bobot nilai kemudian dibagi dengan jumlah responden sebagaimana rumus untuk menghitungkan rata-rata menurut Nazir (2005:380) sebagai berikut:

Jumlah (frekuensi jawaban X bobot nilai)

Nilai kualifikasi $=$ Jumlah responden

Nilai total $=$ Jumlah responden

Selanjutnya, ditetapkan interval nilai guna mendapatkan kualifikasi interpretasi. Kemudian untuk mencari besarnya interval dengan menggunakan range dan jumlah kelas (Nazir (2005:380) dengan rumus sebagai berikut:

$$
\underline{\mathrm{R}} \underset{\mathrm{I}}{=} \mathrm{K}
$$

Keterangan: $\mathrm{I}$ = besarnya interval; $\mathrm{R}=$ jarak pengukuran (nilai tertinggi-nilai terendah); $\mathrm{K}=$ jumlah kelas.

Jadi, intervalnya adalah sebesar:

$$
\mathrm{I}=\frac{4-1}{4}=0,75
$$

Dengan demikian, dapat diketahui interpretasi jawaban responden mengenai kualitas pelayananrumah sakit sebagai berikut:a) nilai kualifikasi 3,26 - 4,00 =dalam kategori sangat baik, b) nilai kualifikasi 2,51 - 3,25 = kategori baik, c) nilai kualifikasi $1,76-2,50=$ kategori kurang baik, dan d) nilai kualifikasi 1,00 $1,75=$ kategori tidak baik.

\section{HASIL DAN PEMBAHASAN}

Kebijakan Pemerintah Daerah dalam Meningkatkan Kualitas Pelayanan Kesehatan Masyarakat Miskin

Kebijakan daerah dalam upaya meningkatkan pelayanan kesehatan bagi masyarakat miskin yang dilakukan oleh Pemerintah Daerah Kabupaten Probolinggo antara lain berupa kebijakan: 1) Memberikan pelayanan kesehatan masyarakat miskin peserta BPJS kesehatan melalui PBI (Penerima Bantuan Iuran); 2) Memberikan pelayanan kesehatan masyarakat miskin peserta Jamkesda dana sharing; 3) Memberikan pelayanan kesehatan melalui surat keterangan miskin/tidak mampu (SKTM). Bentuk kebijakan Pemerintah Kabupaten Probolinggo dalam memberikan pelayanan kesehatan dengan mengeluarkan Peraturan Bupati Nomor 12 Tahun 2015 Tentang Pelayanan Kesehatan bagi Masyarakat Miskin dan Tidak Mampu yang Tidak Termasuk Dalam Jaminan Kesehatan Nasional dan Jaminan Kesehatan Daerah di RSUD Waluyo Jati.

Komitmen Pemerintah Daerah untuk meningkatkan pelayanan terhadap masyarakat miskin tercamtum dalam Peraturan Bupati Probolinggo No. 12 Tahun 2015 memuat berapa hal, yaitu:

1. Pasien miskin dan tidak mampu dapat memperoleh pelayanan kesehatan di Instalasi Gawat Darurat, Rawat Jalan, Rawat Inap, Instalasi Kamar Operasi dan Instalasi penunjang, serta transportasi Ambulan rujukan/jenazah. 
2. Pasien miskin dan tidak mampu yang memerlukan rawat inap harus menandatangani surat persetujuan rawat inap oleh pasien atau keluarganya.

3. Obat-obatan yang dipakai untuk pasien rawat jalan dan rawat inap adalah obat generik dalam Formularium Nasional dan Formularium yang berlaku di RSUD.

4. Bila ada permintaan obat/resep dari dokter untuk jenis obat tertentu seperti obat kemoterapi, insulin, albumin, dan obat tertentu lainnya harus disertai dengan protokol terapi yang ditanda tangani oleh Tim Pengendali pelayanan.

5. Resep obat-obatan dan alat kesehatan diambil di Instalasi Farmasi RSUD dengan sistem satu pintu.

6. Pemakain alat kesehatan seperti IOL, Implant Orthopedi dan Implan lainnya dilaksanakan setelah mendapat persetujuan Tim Pengendali pelayanan.

7. Pemeriksaan penunjang diagnostik dilaksanakan di RSUD.

8. Apabila diperlukan pemeriksaan penunjang yang tidak dapat dilaksanakan RSUD, pasien/sample/jaringan dapat dikirim ke sarana kesehatan/laboratorium yang bekerjasama dengan RSUD.

9. Bagi pasien yang memerlukan rawat inap akan dirawat di Ruang Kelas III (tiga) sesuai penyakitnya.

10. Apabila dibutuhkan tindakan medis operatif, pasien/keluarganya harus mengisi lembar persetujuan tindakan medis (informed consent).
11. Selama dirawat di RSUD, pasien/keluarganya harus mematuhi pengobatan/petunjuk dokter yang merawatnya serta peraturan perundang-undangan yang berlaku.

12. Pemerintah Daerah menanggung biaya rawat jalan dan rawat inap sebesar $100 \%$ bagi bayi baru lahir/anak dari salah satu/kedua orang tuanya peserta Penerima Bantuan Iuran.

13. Pemerintah Daerah menanggung biaya rawat jalan $100 \%$ dan rawat inap sebesar $50 \%$ atau lebih sesuai rekomendasi Direktur untuk pasien yang tidak masuk dalam kepesertaan JKN maupun Jamkesda.

14. Bagi pasien yang memerlukan perawatan lebih lanjut (rujukan ke rumah sakit yang lebih tinggi tingkatannya) biaya transportasi untuk pasien miskin dan tidak mampu menjadi tanggungjawab Pemerintah Daerah.

15. Pemerintah Daerah menanggung biaya transportasi rujukan dan jenazah untuk Pasien Non Kartu JKN dan Non kartu Jamkesda sesuai peraturan perundangundangan yang berlaku.

16. Pemerintah Daerah menanggung biaya transportasi rujukan parsial untuk peserta JKN, peserta Jamkesda dan masyarakat miskin lainnya.

17. Pemerintah Daerah menanggung biaya transportasi rujukan bagi pasien pemegang kartu Jamkesda.

18. Besaran pengurangan/keringanan biaya pelayanan kesehatan bagi pasien Non Kartu JKN dapat ditentukan setelah kelengkapan persyaratan yang 
diverifikasi oleh Tim Verifikasi rumah sakit dan mendapat persetujuan Direktur.

19. Untuk menentukan besaran prosentase keringanan/pengurangan biaya pelayanan yang lebih dari 50\% dilaksanakan oleh Kepala Bidang Keuangan pada RSUD.

20. Pemulasaraan Jenasah bagi masyarakat miskin dan tidak mampu yang menjalani rawat inap kelas III menjadi tanggungjawab Pemerintah Daerah dengan besaran sesuai peraturan perundang-undangan yang berlaku.

21. Pelayanan rawat jalan, rawat inap kelas III, persalinan dan kegiatan operasi bagi pasien HIV/AIDS penduduk daerah ditanggung oleh Pemerintah Daerah.

22. Pemulasaraan Jenasah bagi pasien HIV/AIDS masyarakat miskin dan tidak mampu serta jenazah terlantar biayanya ditanggung Pemerintah Daerah.

23. Pemerintah Daerah menanggung biaya transportasi pemeriksaan laboratorium CD4 ke fasilitas kesehatan lebih tinggi untuk penderita HIV/AIDS ditanggung Pemerintah Daerah.

Adapun sasaran kebijakan terhadap masyarakat miskin dalam memberikan pelayanan kesehatan yang terdapat dalam Peraturan Bupati Probolinggo No. 12 Tahun 2015 adalah meliputi: 1. Masyarakat usia lanjut yang berusia sama dengan atau lebih dari 60 (enam puluh) tahun dan tidak mempunyai kartu kepesertaan asuransi lainnya; 2. Yatim/Yatim piatu yang didaftar di Dinas Sosial Kabupaten Probolinggo; 3. Bayi baru lahir/anak yang sedang dirawat dari salah satu orang tua/kedua orang tua peserta Penerima Bantuan Iuran; 4.Pasien yang memperoleh Surat Pernyataan Miskin (SPM) dari Dinas terkait yang ditunjuk/yang mempenyai kewenangan menerbitkan Surat Pernyataan Miskin (SPM); 5.Gelandangan, pengemis, anak dan orang terlantar serta penghuni panti sosial, dengan menunjukkan surat rekomendasi dari Dinas Sosial Kabupaten Probolinggo; 6. Peserta Program Keluarga Harapan (PKH) yang tidak memiliki kartu Penerima Bantuan Iuran, dengan menunjukkan kartu Program Keluarga Harapan (PKH); 7. Korban bencana dan pasca tanggap darurat yang ditentukan Pemerintah Daerah; 8. Korban musibah masal baik disebabkan bencana alam maupun bencana karena ulah manusia sesuai dengan rekomendasi Direktur RSUD; 9. Kasus KLB seperti demam berdarah, diare, keracunan masal, suspek flu burung, suspek flu babi sesuai dengan peraturan perundang-undangan yang berlaku; 10. Penghuni Lapas dan Rutan, dengan menunjukkan rekomendasi dari Kepala Lapas/Rutan; 11. Tahanan Polri/Kejaksaan, dengan menunjukkan rekomendasi dari Kepolisian/Kejaksaan; 12. Penderita HIV/AIDS dan tidak mempunyai kartu kepesertaan JKN maupun Jamkesda yang ditentukan oleh dokter yang merawat; 13.Penderita dengan kelainan khusus antara lain: Hydrocephalus, Meningocele, Hypospadia, kelainan genetik dan lain-lain (Pasien Program K3S Kabupaten Probolinggo) yang perlu penanganan di RSUD; 14. Penderita permasalahan gizi/gizi buruk yang tidak mempunyai kartu kepesertaan 
JKN maupun Jamkesda yang ditentukan oleh dokter spesialis yang merawat.; 15. Penderita kusta dan paska pengobatannya (reaksi Lepra) yang memerlukan perawatan di RSUD; 16. Penderita Thalassaemia Mayor yang sudah terdaftar pada Yayasan Thalassaemia Mayor Indonesia (YTI) atau yang belum terdaftar namun telah mendapat surat Rekomendasi Direktur RSUD; 17. Penderita Kejadian Ikutan Pasca Imunisasi (KIPI) telah mendapat surat pernyataan Kejadian Ikutan Pasca Imunisasi (KIPI) dari Dokter Spesialis; 18. Penderita gangguan jiwa dan tidak mempunyai kartu kepesertaan JKN maupun Jamkesda yang ditentukan oleh dokter spesialis yang merawat. Biaya pelayanan pengobatan rawat jalan bagi pasien JKN dan Jamkesda yang dilayani di IGD dan tidak ditanggung oleh BPJS dibayar oleh Pemerintah Daerah.

Kebijakan daerah untuk jenis pelayanan rumah sakit yang tidak memiliki kartu JKN atau Jamkesda meliputi beberapa jenis pelayanan, yaitu: 1 . Pelayanan Emergency; 2. Pelayanan Rawat Jalan; a. Pelayanan klinik spesialis, meliputi: Kesehatan Anak dan Tumbuh Kembang; Penyakit Dalam; Kebidanan dan Kandungan termasuk pelayanan Keluarga Berencana; Bedah Umum; THT; Mata; Penyakit Gigi dan Mulut; Ortodonsia; Saraf; Orthopedi; Jantung; VCT dan CST; TB-DOTS; Rehabilitasi Medik dan Fisiotherapi; Gizi; Kesehatan Jiwa; Kulit dan Kelamin; b. Konsultasi medis, pemeriksaan fisik dan penyuluhan kesehatan oleh dokter spesialis /dokter umum. c. Pemeriksaan kehamilan dengan resiko tinggi dan penyulit. d. Pelayanan Keluarga Berencana, termasuk Kontap efektif, Kontap Pasca Persalinan/Keguguran, Pengobatan efek samping dan komplikasi. e. Pemberian obat-obatan sesuai indikasi dan rasional dengan menggunakan obat-obat generik/sesuai Formularium Nasional dan Formularium yang berlaku di RSUD; 3 . Pelayanan Rawat Inap di kelas III/ meliputi : a. Ruang Perawatan Anak; b. Ruang Perawatan OBGYN; c. Ruang Perawatan Bedah Umum dan Bedah Orthopedi; d. Ruang Perawatan Non Bedah Laki-Laki; e. Ruang Perawatan Non Bedah Perempuan; f. Ruang Perawatan Perinatologi; 4.Pelayanan Instalasi Kamar Operasi meliputi : Operasi kecil, operasi sedang dan operasi besar baik elektif maupun emergency; 5. Pelayanan Intensif di ruang ICU, NICU ; 6. Pelayanan Penunjang Medis dan Non Medis meliputi: a. Pelayanan Radiologi; b. Pelayanan Laboratorium Klinik; c. Pelayanan elektromedik : EKG dan EEG; d. Pelayanan Farmasi; e. Pelayanan Instalasi Gizi; f. Pelayanan Ambulans/kereta jenazah; g. Pelayanan Pemulasaraan jenazah.

Sumber pendanaan untuk melaksanakan program meningkatkan pelayanan kesehatan bagi masyarakat miskin adalah dari dana Pusat, dana sharing provinsi dan dana APBD. Program dana Pendamping yang memakai dana APBD. Masyarakat miskin tentunya selama ini tidak semuanya terdaftar dalam Jamkesda. Kebijakan daerah dalam menangani persoalan ini dengan melakukan langkah-langkah sebagai 
berikut: 1 Pertama semua kunjungan pasien di RSUD Waluyo Jati saat registrasi diverifikasi terlebih dahulu di data base BPJS Kesehatan apakah dia terjamin atau tidak jika ya masuk di BPJS Kesehatan, jika tidak menggunakan dana pendamping dari APBD Pemerintah Kabupaten Probolinggo; 2. Kedua jika dia tidak masuk BPJS dia diverifikasi melalui data base Jamkesda dana sharing Propinsi; 3 Langkah terakhir jika dia tidak masuk penjaminan dianjurkan memakai rekomendasi dari Dinas Kesehatan Kabupaten Probolinggo dengan menggunakan (SKM) yang memakai anggaran dana pendamping APBD.

\section{Faktor Hambatan dalam}

\section{Mengimplementasikan Kebijakan}

Pemerintah Daerahdalam memberikan pelayanan kesehatan bagi masyarakat miskin telah mengambil langkah-langkah kebijakan kuratif. Hambatan terkait dengan kuratifuntuk pelayanan kesehatan penderita HIV/AIDS bagi peserta BPJS baik rawat jalan maupun rawat inap BPJS tidak bisa menjaminnya, kecuali jika ada penyakit penyerta (Infeksi Oportunistik). Untuk kasus HIV/AIDS peserta BPJS yang tidak terjamin maka penjaminannya ditanggung oleh dana APBD yaitu dana pendamping. Akibatnya, anggaran untuk dana pendamping di RSUD Waluyo Jati banyak terserap untuk kasus HIV/AIDS yang tiap bulan semakin meningkat jumlah penderitanya.

Kebijakan daerah selama ini dalam memberikan pelayanan kesehatan bagi masyarakat miskin tertumpu pada program Jamkesmas dan Jamkesda, namun dengan berlakunya BPJS kesehatan mengalami berbagai hambatan dalam mengimplementasikannya. Hambatan tersebut antara lain:

a. Hambatan anggaran. Hambatan dana anggaran ini disebabkan oleh: 1). Hambatan untuk bayi baru lahir dari ibu peserta BPJS kesehatan. PBI tidak bisa secara otomatis terjamin oleh BPJS Kesehatan. Banyak prosedur yang harus dipenuhi oleh orang tua bayi yang kebanyakan keluarga miskin dengan pendidikan rendah serta pekerjaan yang tidak pasti. Sebagai akibat prosedur yang sulit tersebut mengakibatkan: a. penjaminannya akan lari semua ke pengguna Surat Keterangan Miskin dengan memakai dana pendamping APBD; $b$. Mengakibatkan dana pendamping sebagian besar terserap oleh pasien yang dirawat di ruang NICU (Neonatal Intensive Care Unit)atau Unit Perawatan Intensif Neonatal. 2). Kasus pelayanan One Day Care tidak bisa tercover oleh BPJS Kesehatan sehingga terpaksa dimasukkan di pelayanan rawat jalan, hal ini merugikan rumah sakit karena pelayanan One Day Care menggunakan unit cosh yang lebih banyak dari pada rawat jalan. 3). Pemeriksaan penunjang untuk pasien rawat jalan melebihi paket INA CBG's dari klaim rawat jalan. 4).Pelayanan Rehabilitasi Medik untuk pasien BPJS Kesehatan dengan adanya dokter spesialis KFR (Spesialis Kedokteran Fisik dan Rehabilitasi) sehingga setiap kunjungan rehabilitasi medik harus bisa terjamin semua. 5).Pelayanan 
MOW (Metode Operasi Wanita) lebih dikenal Tubektomi yang dulunya dijamin rawat jalan oleh BPJS Kesehatan sekarang termasuk pelayanan yang tidak dijamin oleh BPJS Kesehatan. 6). Pelayanan Bedah Tulang oleh dokter spesialis orthopedi rumah sakit dapat dipastikan minus dari sisi keuangan. 7). Sumber dana untuk pembiayaan kesehatan masyarakat miskin berasal dari dana sharing propinsi dan APBD Kabupaten Probolinggo. Bentuk sharing dana antara pemerintah pusat,pemerintah provinsi dan Kabupaten untuk pembiayaan pelayanan kesehatan masyarakat miskin dengan komposisi: 1.Dana sharing pemerintah pusat $100 \%$ dari pusat untuk peserta BPJS-PBI. 2. Dana sharing yang 50\% pemerintah propinsi dan 50\% pemerintah Kabupaten Probolinggo bagi peserta Jamkesda yang punya kartu. 3.Dana sharing pemerintah Kabupaten Probolinggo 100\% dari APBD bagi pengguna Surat Keterangan Miskin (rekomendasi Dinkes), lansia, penderita HIV/AIDS serta beberapa kasus yang dijamin oleh dana pendamping. Namun dana (anggaran) yang disediakan oleh pemerintah pusat maupun pemerintah daerah dirasa masih kurang. Dan yang perlu dipikirkan adalah anggaran untuk biaya hidup bagi yang mengguna pasien miskin terutama untuk pasien yang dirujuk ke rumah sakit provinsi.

b. Regulasipendataan orang miskin. Yang menjadi persoalan regulasi dalam penentuan mereka dalam kategori miskin masih belum ada patokan indikator yang pasti, antara kementerian ataupun instansi pusat dalam membuat indikator tidak sama. Hal ini mempersulit bagi daerah untuk menentukan kemiskinan, oleh karena itu indikator kemiskinan perlu disatukan atau diintegrasikan dalam sebuah regulasi sehingga ada kepastian, aktor atau instansi yang mana harus berperan. Dengan demikian tidak terjadi kesimpangsiuran dalam menentukan kemiskinan. Hambatan dalam persoalan pendataan orang miskin, mereka bila ditanya soal keimiskinan tidak jujur, apalagi tahu kalau akan mendapatkan bantuan atau program. Akibatnya data kemiskinan menjadi membengkak.

c. Sumber daya manusia (SDM). Kendala ketersediaan SDM pelaksana untuk tenaga medis maupun non medis adalah: 1). SDMtenaga medis di RSUD Waluyo Jati masih ada beberapa spesialisasi yang belum terpenuhi kalaupun ada masih belum menjadi dokter tetap sehingga merupakan kendala untuk naik ke tipe rumah sakit yang lebih tinggi seperti dokter penyakit kulit dan kelamin, dan dokter bedah masih kurang. 2). SDM untuk tenaga non medis sudah memadai tetapi untuk penerbit SEP (Surat Eligibilitas Peserta) dari BPJS masih memakai tenaga dari rumah sakit.Namun merupakan tantangan dengan perkembangan jumlah pasien 
maupun kompleksitas status penyakit pasien yang berobat pada saat ini diperlukan tambahan kualifikasi tenaga medis; keterbatasan anggaran pemerintah daerah dalam menyediakan kualifisikasi tenaga medis, sebab banyak dokter yang berprofesi ganda diluar tugas resmi RS. Di RSUD Waluyo Jati Kraksaan kabupaten Problinggo telah dibentuk komite etik yang secara periodik melakukan uji kompetensi kelayakan SDM dokter yang melakukan tugas di RS. Pada saat ini komite etik lebih fokus terkait persoalan akademik SDM dokter. Selama ini keterbatasan anggaran pihak RSUD maupun Pemerintah Kabupaten Probolinggo dalam melakukan program pelatihan tenaga medis maupun non medis. Kebijakan untuk meningkatkan kualitas pelayanan kesehatan bagi masyarakat miskin, maka melakukan langkah-langkah dengan merekrut SDM untuk pelaksana tenaga medis maupun non medis sebagai berikut ini:Pertama, untuk rekrutmen tenaga medis dilakukan dengan menugaskan beberapa dokter untuk yang menempuh spesialisasi, atau melakukan MOU dengan RSUD Dr.Sutomo Surabaya terkait kebutuhan akan dokter spesialis. Selain itu merekrut dokter spesialis status honorer yang kemudian diangkat menjadi tenaga PNS.Kedua, merekrut tenaga non medis dengan tenaga honorer/kontrak dari pemeritah Kabupaten Probolinggo atau tenaga yang digaji oleh RSUD Waluyo Jati sendiri.

\section{Kualitas Layanan Kesehatan Pasien Miskin}

Peralihan kebijakan dari program Jamkesmas, Jamkesda ke Program JKN berdampak terhadap kualitas pelayanan kesehatan masyarakat miskin. Untuk mengetahui kualitas pelayanan kesehatan yang diselenggarakan oleh pihak rumah sakit dapat dilihat dari berbagai kondisi indikator yang antara lain kualitas sarana dan prasarana kesehatan, sistem dan prosedur, kualitas aparatur pelayanan kesehatan.Penilaian pasien masyarakat miskin terhadap kualitas pelayanan Kesehatan RSUD Waluyo Jati Kraksaan Kabupaten probolinggo adalah:

a. Penilaian terhadap sarana dan prasarana rumah sakit. Sarana dan prasarana ini meliputi:A) Jangkauan lokasi menuju RSU Kabupaten Problinggo relatif terjangkau. Transportasi umum menuju rumah sakit relatif mudah diakses, karena berada dijalur utama yang menghubungkan dengan angkutan umum dari beberapa kota sekitar Kabupaten Probolinggo dan merupakan jalan nasional yang menghubungkan Jawa-Bali. Untuk masyarakat yang berada di pedesaan kalau tidak memiliki alat transporasi agak kesulitan, mereka memakai alat transporatsi ojek, ataupun diantarkan tetangganya. Untuk sarana transportasi ke rumah sakit ini dapat dikategorikan baik dengan nilai rata-rata 3,0. B) Lingkungan rumah sakit terkait luas 
bangunan dan lahan dianggap luas dan lingkungan nyaman dengan banyak pepohonan, namun kondisi lahan parkir dirasakan masih kurang luas, terutama parkir untuk mobil. Akibatnya parkir mobil tidak tertata dengan rapi. Disamping itu lingkungan rumah sakit secara umum baik atau bersih, namun masih banyak kondisi yang dianggap kurang bersih atau kotor karena masih ada sudut-sudut tertentu yang tidak bersih. Bahkan ada kamar mandi rawat inap ada yang kotor/tidak bersih, dan atap ruangan yang bocor. Kondisi kamar mandi yang kotor ini menunjukkan ketidak konsistennya pihak manajemen rumah sakit untuk menjaga kebersihan atau ketidak tegasan pihak manajemen untuk menindak atau menegur keluarga atau pengunjung pasien yang tidak mau menjaga kebersihanrumah sakit sebagai barang publik. Kondisi lingkungan yang demikian ini masih dinilainya kurang baik (2,45). C) Peralatan medik dianggap lumayan lengkap dan banyak perkembangannya. Banyak peralatan medik yang relatif baru, ada pula peralatan medis usia tua masih relatif terpelihara dan bisa dioperasikan. Untuk sarana laboratoriumnya ada pembatasan item yang diperiksanya, tidak lagi leluasa. Selain itu hanya satu (1) tindakan rehabilitasi medik saja, tidak boleh lebih.Untuk kelengkapan sarana medik dan penunjang ini dinilai oleh pasien nilai rata-rata sangat baik $(3,55)$. Hal ini dengan melihat perkembangan rumah sakit saat ini telah menjadi rujukan diwilayah sekitar Kabupaten Probolinggo, yaitu Kota Probolinggo dan Kabupaten Situbondo. D) Kondisi sarana informasi dan komunikasi dinilai responden cukup lengkap, bahkan dinilai rata-rata baik $(2,85)$. Didekat pintu masuk utama terdapat pusat informasi dan terdapat pula petugas yang menjaganya. Dalam penyampaian informasi memakai pengeras suara, relatif tersedianya papan pengumuman di beberapa ruangan.

b. Penilaian sistem prosedur administrasi dan informasi pelayanan ini meliputi beberapa hal, yaitu: a) Penilaian pasien terkait dengan administrasi rekam medis (satus pasien). Kecepatan pengurusan adminsitrasi rekammedis dinilai cukup cepat dan baik $(2,62)$ dalam mencari status pasien, terutama pasien yang rawat jalan; b) Kejelasan jaminan klaim pengobatan pengobatan kadangkadang dirasakan oleh pasien/keluarga pasien miskin masih berbelit-belitnya pelayanannya, dan ada pembatasan pelayanan. Namun demikian kejelasan klaim obat dinilai baik $(2,95)$; b) Penilain terkait dengan klaim obatobatan pada kenyataannya terkadang tidak semua obat ada dan bisa diklaim, sehingga pasien maskin harus mengeluarkan biaya tambahan sendiri. Klaim obat maupun item pengobatan sekarang lebih terbatas. Pada umumnya responden menyatakan bahwa dalam pengurusan obat dan 
prosedur klaim tidak dipersulit dan mereka melayaninya dengan cepat; c) Prosedur klaim nampak lebih sulit karena terbatasnya item obat. Adanya pembatasan dan minimnya penyediaan obat dan sistem rujukan yang tidak bagus dan terbatas. Namun demikian, terkait prosedur pelayanan kesehatan tidaklah dipahami oleh semua pasien masyarakat miskin secara keseluruhan. Walaupun demikian prosedur perobat ini dinilai oleh pasien dianggap baik $(2,60)$.

\section{Tabel 2. Penilaian Pasien Terhadap Kualitas Pelayanan RSUD}

\begin{tabular}{|c|c|c|c|}
\hline \multirow[b]{2}{*}{ No } & \multirow[b]{2}{*}{ Aspek Pelayanan Kesehatan } & \multicolumn{2}{|c|}{ Kualitas Pelayanan } \\
\hline & & $\begin{array}{c}\text { Nilai } \\
\text { rata-rata }\end{array}$ & $\begin{array}{l}\text { Nilai } \\
\text { kualifikasi }\end{array}$ \\
\hline A. & Sarana prasarana rumah sakit & 3.06 & baik \\
\hline 1 & Jangkauan kemudahan ke RS & 3,20 & baik \\
\hline 2 & Hambatan berobat sebab jangkauan ke RS & 3,25 & baik \\
\hline 3 & Kenyamanan suasana lingkungan RS & 2,45 & Kurang baik \\
\hline 4 & Kelengkapan sarana/prasarana medik & 3,55 & Sangat baik \\
\hline 5 & Sarana/prasarana informasi dan komunikasi & 2,85 & baik \\
\hline B. & $\begin{array}{l}\text { Sistem administrasi, prosedur pelayaan } \\
\text { rumah sakit }\end{array}$ & 2,89 & baik \\
\hline 1 & $\begin{array}{l}\text { Kecepatan pengurusan administrasi } \\
\text { rekammedis (status pasien) }\end{array}$ & 2,62 & baik \\
\hline 2 & Kejelasan jaminan klaim pengobatan & 2,95 & baik \\
\hline 3 & $\begin{array}{l}\text { Kejelasan prosedur memperoleh dan } \\
\text { menggunakan kartu berobat }\end{array}$ & 2,25 & Kurang baik \\
\hline 4 & Kemudahan prosedur berobat & 2,60 & baik \\
\hline 5 & Kejelasan prosedur pengaduan pelayanan & 3,47 & Sangat baik \\
\hline 6 & Tanggapan atas pengaduan pelayanan & 3,75 & Sangat baik \\
\hline 7 & Kondisi pelayanan informasi RS & 2,60 & baik \\
\hline C. & SDM Petugas: & 3,53 & Sangat baik \\
\hline 1 & Kepastian keberadaan petugas yang melayani & 3.87 & Sangat baik \\
\hline 2 & $\begin{array}{l}\text { Kedisiplinan petugas dalam memberikan } \\
\text { pelayanan }\end{array}$ & 3.80 & Sangat baik \\
\hline 3 & $\begin{array}{l}\text { Tanggung jawab petugas dalam memberikan } \\
\text { pelayanan }\end{array}$ & 3.77 & Sangat baik \\
\hline 4 & $\begin{array}{l}\text { Kemampuan petugas dalam memberikan } \\
\text { pelayanan }\end{array}$ & 3.72 & Sangat baik \\
\hline 5 & Kecepatan pelayanan & 3.55 & Sangat baik \\
\hline 6 & Keadilan untuk mendapatkan pelayanan & 3.37 & Sangat baik \\
\hline 7 & Keramahan \&kesopanan petugas & 3,02 & Baik \\
\hline 8 & $\begin{array}{l}\text { Kejelasan penyampaian informasi berkaitan } \\
\text { dengan jenis penyakit pasien oleh petugas }\end{array}$ & 3.00 & baik \\
\hline 9 & $\begin{array}{l}\text { Keamanan (resiko kesalahan praktek) } \\
\text { pelayanan }\end{array}$ & 3.85 & Sangat baik \\
\hline 10 & Kesungguhan petugas dalam memberikan & 3.05 & baik \\
\hline
\end{tabular}




\begin{tabular}{|c|c|c|c|}
\hline \multirow[b]{2}{*}{ No } & \multirow[b]{2}{*}{ Aspek Pelayanan Kesehatan } & \multicolumn{2}{|c|}{ Kualitas Pelayanan } \\
\hline & & $\begin{array}{c}\text { Nilai } \\
\text { rata-rata }\end{array}$ & $\begin{array}{c}\text { Nilai } \\
\text { kualifikasi }\end{array}$ \\
\hline 11 & $\begin{array}{l}\text { pelayanan } \\
\text { Kepedulian (empati) petugas dalam } \\
\text { memberikan pelayanan kepada pasien }\end{array}$ & 3.82 & Sangat baik \\
\hline & Jumlah rata-rata & 3,16 & baik \\
\hline
\end{tabular}

Sumber: Data Primer diolah

c. Penilaian pasien masyarakat miskin terhadap SDM aparatur dalam memberikan pelayanan kesehatan dinilai tahu apa yang harus dikerjakan. Oleh karena itu tanggung jawab petugas dalam memberikan pelayanandinilai oleh pasien dalam kategori sangat baik (3.77), demikian juga kemampuan petugas dalam memberikan pelayanan dinilai sangat baik $(3,72)$. Akan tetapi terkadang masih ditemukan petugas yang tidak segera menangani pasien karena menunggu lama perintah dokter, dokter yang sering terlambat datang ke rumah sakit. Kondisi keramahan petugas pada umumnya cukup ramah dan sopan dalam memberikan pelayanan kepada pasien masyarakat miskin $(3,02)$. Kondisi empati petugas rumah sakit bersedia mendengar, memberi saran atas keluhan pasien (3.00). namun masih ditemukannya pasien yang menunggu lama mendapatkan pelayanan pengobatan. Disamping itu terkadang petugas kurang mengerti kebutuhan pasien, kalau tidak ditanya oleh pasien sehubungan kondisi kesehatan pasien atau keluarganya yang sakit maka petugas tidak berinisiatif memberi menjelaskan. Perilaku petugas, dirasakan masih ada perbedaan antara pasien maskin dan non maskin dalam hal kecepatan dalam memberikan pelayanan pengobatan, walaupun demikian dinilai baik dan peduli terhadap pasien (3.37).

d. Berdasarkan penilaian responden pasien masyarakat miskin terhadap kualitas pelayanan RSUD Waluyo Jati Kraksaan Kabupaten Probolinggo untuk variabel prasarana dan sarana dalam kategori baik (3.06). Demikian pula untuk variabel sistem administrasi, prosedur pelayanan rumah sakit dalam kategori baik $(2,89)$. Pada variabel kualitas sumber daya manusia (SDM) aparatur pelayanan kesehatan dalam ketegori sangat baik $(3,53)$. Kualitas pelayanan rumah sakit secara keseluruhan menurut persepsi pasien miskin dalam kategori baik $(3,16)$.

\section{KESIMPULAN DAN SARAN}

Kebijakan daerah dalam upaya meningkatkan pelayanan kesehatan bagi masyarakat miskin yang dilakukan oleh Pemerintah Daerah Kab. Probolinggo berupa pelayanan peserta BPJS kesehatan melalui PBI (Penerima Bantuan Iuran); 
peserta Jamkesda dana sharing; melalui surat keterangan miskin/tidak mampu (SKTM). Bentuk konsistensi dalam memberikan pelayanan kesehatan dengan mengeluarkan Peraturan Bupati No. 12/2015 Tentang Pelayanan Kesehatan bagi Masyarakat Miskin dan Tidak Mampu yang Tidak Termasuk Dalam JKN dan Jaminan Kesehatan Daerah di RSUD Waluyo Jati Kraksaan.

Faktor yang menjadi hambatan dalam implementasi kebijakan terutama terletak pada SDM tenaga medis utamanya untuk tenaga dokter spesialis yang dirasakan masih kurang, kalaupun ada masih belum menjadi dokter tetap sehingga merupakan kendala untuk naik ke tipe rumah sakit yang lebih tinggi, yaitu tipe B. Selain itu SDM untuk tenaga non medis sudah memadai tetapi untuk penerbit SEP (Surat Eligibilitas Peserta) dari BPJS masih memakai tenaga dari rumah sakit. Selain itu faktor dalam menentukan indikator kemiskinan, pihak pemerintah kabupaten mengalami kesulitan sebab tolok ukur/indikator dalam mentukan kemiskinan antara instansi satu dengan yang lainnya berbeda. Faktor kesulitan di pihak masyarakat miskin bila pasien akan dirujuk ke rumah sakit milik Provinsi kebanyakan keluarganya tidak mau karena mengalami kesulitan untuk biaya hidup selama menunggu pasien di rumah sakit dan biaya untuk tranportasi yang jaraknya jauh.

Implementasi kebijakan dalam meningkatkan pelayanan kesehatan terhadap pasien miskin telah dapat memberikan kontribusi positif terhadap kualitas pelayanan kesehatan. Kualitas pelayanan RSUD Waluyo Jati Kraksaan Kabupaten Probolinggo secara keseluruhan dalam kategori baik. Walaupun dalam indikator tertentu masih kurang baik dan diperlukan suatu perbaikan-perbaikan dalam memberikan pelayanan kesehatan

\section{DAFTAR PUSTAKA}

Aditama, T.Y. (2004). Manajemen Rumah Sakit, Edisi Kedua. Jakarta: Universitas Indonesia Press.

Azwar, A. (1996). Pengantar Administrasi Kesehatan. Jakarta:Binarupa Aksara.

Ayuningtyas, D. (2014). Kebijakan Kesehatan Prinsip dan Praktek. Jakarta:Raja Grafindo Persada

Corputty, L.S., Dkk. (2014)." Dampak Kebijakan Pelayanan Kesehatan Gratisterhadap Kepuasan Pasien Dalam Menerima Pelayanan Kesehatan Puskesmas Di Kota Ambon". Jurnal Kebijakan Kesehatan Indonesia . Vol. 02, No. 02 Juni. 2013

Denhardt, J.V., Denhardt, R.B. (2013). Pelayanan Publik Baru Dari manajemen Steering ke Serving. Yogyakarta: Kreasi Wacana.

Donabedian, A.(1998). The Quality Care. New York:Pragrave.

Eriyanto.(1999). Metodologi Polling Memberdayakan Suara Rakyat. Bandung: Remaja Rosdakarya.

Fitriyah, L. dkk. (2014). Pengantar Psikologi Umum. Jakarta:Prestasi Pustaka.

Giddens, A. (2003). Beyond Left and Right (Tarian "Ideologi Alternatif" di atas Pusara Sosialisme dan Kapitalisme). Yogyakarta:IRCiSoD

Grindle, Merilee S. (1980). Politics and Policy Implementation in the Third World. Priceton, New Jersey: Princeton University Press. 
Hughes, O. E. (1994). Publik Manajemen and Administration and introduktion, Martin press.

Keban, Y. T. (2008). Enam Dimensi Strategis Administrasi Publik Konsep, Teori dan Isu. Yogjakarta: Gava Media.

Machmud, R., dkk. (2014). "Survei Kepuasan Dan Manajemen Keluhan Pasien Diabetes Melitus Terhadap Pelayanan Kesehatan Prolanis Askes Di Rumah Sakit Pemerintah Propinsi Sumatera Barat". Jurnal Kebijakan Kesehatan Indonesia. Vol. 03. No. 03 September 2014.

Miles, M.B., Huberman. A.M. (2014). Qualitative Data Analysis A Methods. California: SAGE Publication Ltd. Edition 3

Nazir, M. (2003). Metode Penelitian. Jakarta: Ghalia Indonesia.

Notoatmadjo, S. (2010). Ilmu Perilaku Kesehatan. Jakarta: Rineka Cipta.

Ratminto., Winarsih, A. (2009). Menejemen Pelayanan: Pengembangan Model Konseptual Penerapan Citizen's Charter dan Standar Pelayanan Minimal. Yogyakarta:Pustaka Pelajar, Cetakan VI.

Parsons, W. (2005). Public Policy: Pengantar Teori dan Prakik Analisis Kebijakan. Jakarta: Kencana.

Trinsnantoro, L. (2005). Memahami Penggunaan Ilmu Ekonomi Dalam Manajemen Rumah Sakit. Yogyakarta: Gadjah Mada University Press.

Triwibowo, D., Subono, N.U. (2009). Meretas arah Kebijakan Sosial baru di Indonesia. Jakarta:Pustaka LP3ES Indonesia.

Yami, Z. (2004). Manajemen Kualitas Produk dan Jasa. Yogyakarta: Ekonisia

Winarno, B. (2014). Kebijakan Publik: Teori, Proses, dan Studi Kasus. Jakarta: CAPS (Center of Academic Publishing Service)
Sarwono, S. W. (2013). Pengantar Psikologi Umum. Jakarta: Rajawali Press

Sekaran, U. (2006). Methodologi Penelitian Bisnis, Buku 1 dan 2, Salemba Empat, Edisi 4, Jakarta

Soekanto, S. (1987). Sosiologi Suatu Pengantar. Yogyakarta: Rajawali Press

Sugiyono (2013). Metode Penelitian Kombinasi (Mixed Methods).

Yogyakart: Alfabeta

\section{Perundangan dan Peraturan lainnya:}

Undang-Undang Nomor 40 tahun 2004, tentang Sistem Jaminan Sosial Nasional (SJSN)

Undang-Undang Nomor 24 tahun 2011, tentang BPJS

Surat Keputusan Menteri Pendayagunaan Negara

Nomor:KEP/25/

M.PAN/2/2004 tentang Pedoman Umum Penyusunan Indeks Kepuasan Masyarakat Unit Pelayanan Instansi Pemerintah

\section{Website:}

Majalah: Glabal Sehat, edisi 22, 10 Februari10 Maret 2014.

http:/ / remanda-

community.blogspot.com/2013/10/ pemodelan-papalele-sebagai-modelbudaya. html, diunduh 8-7-2015.

http:/ / ayuardhita.blogspot.com/2012/10/ teori-ekonomi-1-barangsubstitusi.html/diunduh 11-7-20145

http://www. map.ugm.ac.id/index.php) Teori Ekonomi 1] Barang Substitusi, Surplus Produsen, dan Efek Pergeseran Kurva Permintaan dan Penawaran Barang Substitusi, diunduh 11-7-2014

http://direktori.umy.ac.id/uploads/skrips i2/2004052008), diunduh 11-7-2014. 
http:// www.imamboll.com/2014/03/kelu han-dan-kekurangan-programbpjs.html, diunduh 14/7/2015

http://www.nefosnews.com/post/ekbis/d itemukan-87-masalah-pentingseputar-bpjs diunduh, 14/7/2015.

http://www.harianterbit.com/read/2014/ 06/12/3595/0/29/hasil-Audit-BPKBPJS-Banyak-Masalah, diunduh $14 / 7 / 2015$

http:/ / bpjs-kesehatan.go.id/ berita-187catatan-agus-pambagio-kelangkaanobat-di-balik-layar-bpjskesehatan.html, diunduh, 14/7/2015

http://www.anggaran.depkeu.go.id/athu mbs/apbn/Kemiskinan.pdf/diunduh 6/8/2015)

http://www.antarajatim.com, diunduh 26/2/2015

http://www.probolinggokab.bps.go.id, diunduh $26 / 2 / 2015$ 